\title{
EFFICIENCY IMPROVEMENT FOR SUGAR PLANT BOILER DEPARTMENT WORK BASED ON BOILER UNITS OPTIMAL LOADS DISTRIBUTION
}

\author{
Y. Skakovsky ${ }^{1}$, A. Babkov ${ }^{2}$, E. Mandro ${ }^{3}$ \\ ${ }^{1,2,3}$ Odessa national academy of food technology, Odessa, Ukraine \\ ${ }^{1}$ ORCID: 0000-0003-4888-4469; ${ }^{2} 0000-0002-9167-7804$
}

Copyright (C) 2017 by author and the journal "Automation technological and business - processes". This work is licensed under the Creative Commons Attribution International License (CC BY). http://creativecommons.org/licenses/by/4.0/

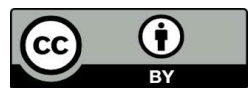

ONAFT

Open Access

\begin{abstract}
The results of laboratory and industrial researches made it possible to propose efficiency improvement method for sugar plant boiler department work. As a partial work efficiency criterion for each boiler unit, its efficiency factor is considered. Its identification, as for non-linear load function is carried out according to the test results given in regime maps. Maximization for general criterion is reached by optimal loads distribution between parallel operating boiler units, while observing constraints like equality to ensure the required steam amount needed for consumers, and like inequalities formed on the base of boiler units' characteristics. The result of task solution is presented with formulas to calculate and determine the optimum loads values of each boiler unit included in operation, that made it possible to implement the subsystem in operating SCADA information-control system for CHP plant boiler department. Algorithm and application program have been developed, as well as a main screen form for CHP head automated workplace. The optimum load values of each boiler unit are used as tasks in boiler load stabilization circuit in period among calculations. Research results will be used to modernize the existing control system at the sugar plant and in the educational process.
\end{abstract}

Keywords: Boiler unit, boiler department, optimal load distribution, criteria, SCADA system, automated workplace, algorithm, program.

\section{Introduction}

For Odessa National Academy of Food Technologies (ONAFT) in the framework of Research Institute contract themes were performed works on providing scientific and technical assistance in modernization of automation systems for boiler units in CHP plant to improve the efficiency of its operation at Krasilovskyi beet-sugar factory (Khmelnitsky region).

In today's rising prices for import energy carriers the efficiency increasing for energy-intensive steam generating equipment is rather actual task, considering the need to improve profitability and competitiveness in competitive environment.

In the process of work performing, modernization of boiler units' automation systems with DKVr type that works on a common steam collector in the CHP plant was carried out. The system includes monitoring and control functions, in particular boiler unit operating mode optimization based on the proposed criterion $[1,2]$, as well as the technology of "thin clients" is used for technical structure implementation [3].

Typically, the boiler units' control is conducted on the basis of regime maps, compiled according to the test results for three load modes. In parameters set efficiency factor is defined (EF, \%), and calculated by reverse heat balance method.

Controlling a group of boilers working for a common collector, need to choose control method that ensures boiler department's maximum energy efficiency appears. There are well known systems that are implemented at a number of enterprises where management is built on principle of separating several boilers with high efficiency factor for operation in the basic mode and one operating in adjusting mode that ensures pressure stabilization in common steam collector [1]. However, this method does not provide the maximum energy efficiency of boiler department.

The application of control method based on principle of optimal load distribution among parallel operating units is proposed.

Main technical solutions

Inspections carried out at a number of sugar plants have shown that, as a rule, two to five boiler units operate in boiler department, boiler units capacity may differ, for example, Krasilovskyi sugar plant: four DKVr-10-23 boiler units and one DKVr-16-23 boiler unit (the first digit is the rated steam capacity, the second is the maximum drum pressure). Each boiler unit 
has an individual energy-efficient characteristic. In accordance with the well-known universal general technical principle [4] of using aggregates with high unit capacity advantages, the optimal solution will be the most complete load of the most powerful units and switching off the most low-power ones. For this particular case, it is recommended that boiler unit with more steam generation and better energy efficiency will be included in work with the maximum load. For other boiler units with close passport and different energy-efficient characteristics, it is expedient to solve the problem of optimal loads distribution, considering that one of boiler units is always off (stays in reserve), due to excessive units total capacity (20-25\%).

Various options for regulating steam (thermal) load of boiler units operating in group are known: regulation of superheated steam pressure (after superheater), pressure in boiler drum (in absence of superheater), load stabilization (steam flow from boiler unit to common collector).

The last option will be considered in control system operation, regarding known connection between boiler steam mass flow and the difference between pressure in boiler drum and pressure in common steam collector, taking into account steam section, steam density, flow coefficients, vapor expansion, if necessary, it allows to complete direct and reverse recalculation of the indicated flow rate and steam pressure in drum:

$$
f_{i}=\varphi_{i} \sqrt{\left(p_{i}-p_{k}\right)}
$$

where process variables controlled in the information system are:

$f_{i}$ - steam flow from the $i$-th boiler unit to common collector, $\mathrm{kg} / \mathrm{s}(\mathrm{t} / \mathrm{h})$;

$p_{i}-$ drum pressure in the $i$-th boiler unit, MPa (atm);

$p_{k}$ - pressure in common collector, $\mathrm{MPa}(\mathrm{atm})$;

$\varphi_{i}$ - set of parameters (coefficients), $(\mathrm{kg} / \mathrm{s}) /(\mathrm{MPa})^{1 / 2}-$ uncontrolled in system.

The last parameter is determined by processing boiler department information system data files for representative time interval for each boiler unit, for example, the average value for boiler unit № $3 \varphi_{i}=7,872 \pm 0,613(\mathrm{~kg} / \mathrm{s}) /(\mathrm{MPa})^{1 / 2}$.

Therefore, reverse recalculation based on (1) is carried out according to the dependence:

$$
p_{i}=\frac{f_{i}^{2}}{\varphi_{i}^{2}}+p_{k}
$$

There is a task to formulate statement of problem for optimal loads distribution between parallel operating boiler units for particular case under consideration:

1. Three $(n=3)$ of four installed DKVr-10-23 boiler units simultaneously operate in group with close passport and various energy-efficient characteristics (boiler units №1, №2, №3).

2. The energy-efficient characteristics of each boiler unit efficiency factor $\left(\dot{\eta}_{i}\right)$ are determined experimentally on the base of regime maps data for corresponding boiler units: $\eta_{i}=\eta_{i}\left(f_{i}\right), i=1, \ldots, 3$. This parameter is regarded as a particular efficiency criterion. $\eta_{i}=\eta_{i}\left(f_{i}\right)$ functions are continuous, monotonically increasing.

3. As a target function, general efficiency criterion $\eta_{0}=\sum_{i=1}^{n} \frac{\eta_{i}}{n}$ will be defined, its maximization is reached due to optimal loads distribution among operating boiler units.

4. Total steam load for $F$ department is determined by needs of turbine department, plant heat consumers, also constraints on inequalities type for each boiler unit are specified:

5.

$$
f_{i}^{l l} \leq f_{i} \leq f_{i}^{u l}
$$

The condition for optimal load distribution among parallel aggregates is known, obtained using the Lagrange multiplier method in [4] for general statement of similar problem.

For particular case under consideration - three operating boiler units, the equality of partial derivatives for $\left(\eta_{i}\right)$ efficiency criterion will consist of optimality condition with respect to load of each boiler unit at total capacity equal to given:

$$
\left\{\begin{array}{c}
\frac{\partial \eta_{1}\left(f_{1}\right)}{\partial\left(f_{1}\right)}=\frac{\partial \eta_{2}\left(f_{2}\right)}{\partial\left(f_{2}\right)}=\frac{\partial \eta_{3}\left(f_{3}\right)}{\partial\left(f_{3}\right)} \\
f_{1}+f_{2}+f_{3}=F
\end{array}\right.
$$


The identification of boiler units' energy efficiency models $\eta_{i}=\eta_{i}\left(f_{i}\right)$ is performed by interpolation and approximation of nonlinear functions by quadratic dependencies in three common points, according to the data shown in regime maps:

$$
\begin{gathered}
\eta_{1}\left(f_{1}\right)=a_{1} f_{1}^{2}+b_{1} f_{1}+c_{1} \\
\eta_{2}\left(f_{2}\right)=a_{2} f_{2}^{2}+b_{2} f_{2}+c_{2} \\
\eta_{3}\left(f_{3}\right)=a_{3} f_{3}^{2}+b_{3} f_{3}+c_{3} \\
\eta_{4}\left(f_{4}\right)=a_{4} f_{4}^{2}+b_{4} f_{4}+c_{4}
\end{gathered}
$$

The calculated models (4) adequately indicate functions $\dot{\eta}_{i}=\dot{\eta}_{i}\left(f_{i}\right)$ in operating ranges of each boiler unit loads:

$$
f_{i}^{l l} \leq f_{i} \leq f_{i}^{u l}
$$

where $f_{i}^{u l}, f_{i}^{l l}$ - upper and lower limit range for each boiler unit, for control objects under consideration, according to statistical data obtained during the operating season, such limits are:

$$
f_{i}^{l l}=4,0 \mathrm{t} / \mathrm{h} ; f_{i}^{u l}=11,5 \mathrm{t} / \mathrm{h} .
$$

Solving system of equations (3) and taking into account the obtained models (4), with respect to required $f_{i}^{\text {opt }}$ loads for three operating boiler units.

Taking the partial derivatives (3) and equating them in pairs, a system of algebraic equations is defined:

$$
\left\{\begin{array}{c}
2 a_{1} f_{1}+b_{1}=2 a_{2}+b_{2} \\
2 a_{1} f_{1}+b_{1}=2 a_{3}+b_{3} \\
f_{1}+f_{2}+f_{3}=F
\end{array}\right.
$$

System of three equations (5) with three unknown variable is to be solved both with standard mathematical packages (MathCad, MathLab) and with analytical method.

The analytical method allowed obtaining solutions as calculation formulas for optimum loads for each of three operating boiler units:

$$
\begin{gathered}
f_{3}^{o p t}=\frac{2 a_{1} a_{2} F-\left(a_{1}+a_{2}\right) b_{3}+a_{1} b_{2}+a_{2} b_{1}}{2\left(a_{1} a_{2}+a_{1} a_{3}+a_{2} a_{3}\right)}, \\
f_{2}^{o p t}=\frac{2 a_{1} a_{3} F-\left(a_{1}+a_{3}\right) b_{2}+a_{3} b_{1}+a_{1} b_{3}}{2\left(a_{1} a_{2}+a_{1} a_{3}+a_{2} a_{3}\right)}, \\
f_{1}^{o p t}=\frac{2 a_{2} a_{3} F-\left(a_{2}+a_{3}\right) b_{1}+a_{3} b_{2}+a_{2} b_{3}}{2\left(a_{1} a_{2}+a_{1} a_{3}+a_{2} a_{3}\right)} .
\end{gathered}
$$

Equivalently, calculation formulas were obtained in case for two boiler units operating with close passport and different energy-efficient characteristics:

$$
\begin{aligned}
& f_{1}^{o p t}=\frac{2 a_{2} F-b_{1}+b_{2}}{2\left(a_{1}+a_{2}\right)} \\
& f_{1}^{o p t}=\frac{2 a_{1} F-b_{2}+b_{1}}{2\left(a_{1}+a_{2}\right)}
\end{aligned}
$$

At this rate, in order to gain the task, optimal load distributions' analytical expressions for three and two operating aggregates are obtained. To perform numerical calculations and include this task in option of operating automated workplace (SCADA-system), it is necessary to arrange the initial data from regime maps to approximate functions $\eta_{i}=\eta_{i}\left(f_{i}\right)(4)$.

Data processing of regime cards for boiler units operating (Krasilovskyi sugar plant) allowed obtaining the following data on efficiency factor, $\%$ for three main load modes $\eta_{i}\left(f_{i}\right)-6,0 t / h ; 8,0 t / h ; 10,0 t / h$ for each DKVr-10/23 boiler unit: 
№1 $\dot{\eta}_{1}\left\{\left(f_{11} ; \dot{\eta}_{11}\right) ;\left(f_{12} ; \dot{\eta}_{12}\right) ;\left(f_{13} ; \dot{\eta}_{13}\right)\right\}=\{(6,0 ; 90,0) ;(8.0 ; 90,6) ;(10,0 ; 91,0)\}$

№2 $\dot{\eta}_{2}\left\{\left(f_{21} ; \dot{\eta}_{21}\right) ;\left(f_{22} ; \dot{\eta}_{22}\right) ;\left(f_{23} ; \dot{\eta}_{23}\right)\right\}=\{(6,0 ; 90,5) ;(8.0 ; 92,1) ;(10,0 ; 92,4)\}$

№3 '́n $3\left\{\left(f_{31} ; \dot{\eta}_{31}\right) ;\left(f_{32} ; \dot{\eta}_{32}\right) ;\left(f_{33} ; \dot{\eta}_{33}\right)\right\}=\{(6,0 ; 90,2) ;(8.0 ; 91,5) ;(10,0 ; 92,0)\}$

№4 $\dot{\eta}_{4}\left\{\left(f_{41} ; \dot{\eta}_{41}\right) ;\left(f_{42} ; \dot{\eta}_{42}\right) ;\left(f_{43} ; \dot{\eta}_{43}\right)\right\}=\{(6,0 ; 88,5) ;(8.0 ; 90,5) ;(10,0 ; 91,0)\}$.

Approximation of data given in (11) by quadratic dependences (with three points) is performed analytically (results are summarized in Table 1), and also by software (on-line mode WolframAlfa program - results are given in Table 2). The results obtained by two methods are corresponding.

Table 1 - Parameters of energy-efficient models for boiler units №1, №2, №3, №4

\begin{tabular}{|c|c|c|c|}
\hline №oo boiler units & $a_{i}$ & $b_{i}$ & $c_{i}$ \\
\hline 1. & $-0,025$ & 0,65 & 87 \\
\hline 2. & $-0,164$ & 3,093 & 81,5 \\
\hline 3. & $-0,1$ & 2,05 & 73,5 \\
\hline
\end{tabular}

Before implementing program task in SCADA-system, calculations of test cases are performed.

The programming was performed in SCADA-program "INDEL4", "Calculator" option (the developer - private enterprise "Infotekhprom", Poltava, Ukraine) operating at the Krasilovskyi sugar plant. The developed subsystem is built into the SCADA-system, which operates as part of CHP plant head automated workplace.

Table 2 - Approximation of $\eta_{i}=\eta_{i}\left(f_{i}\right)$ functions with WolframAlfa program

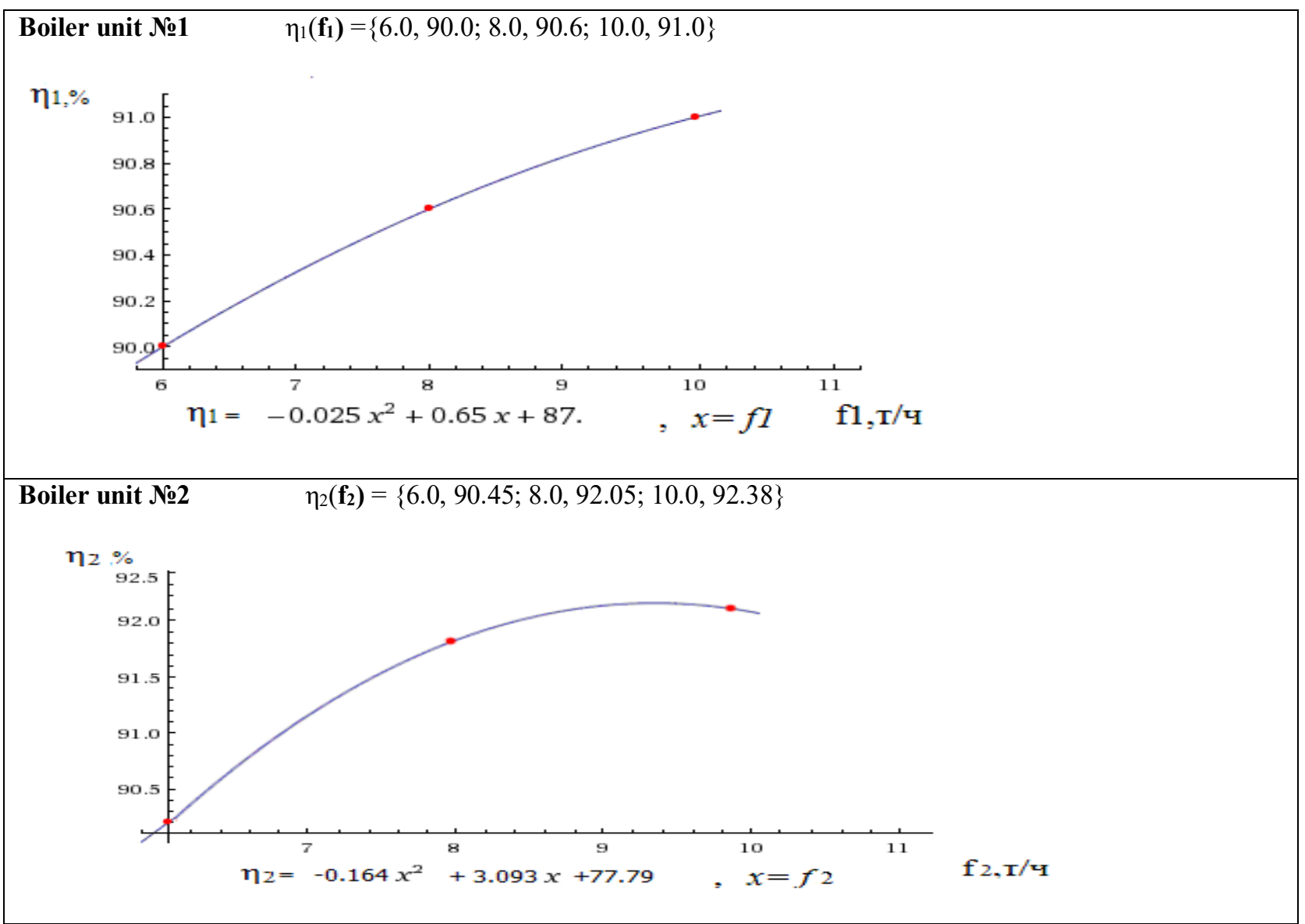




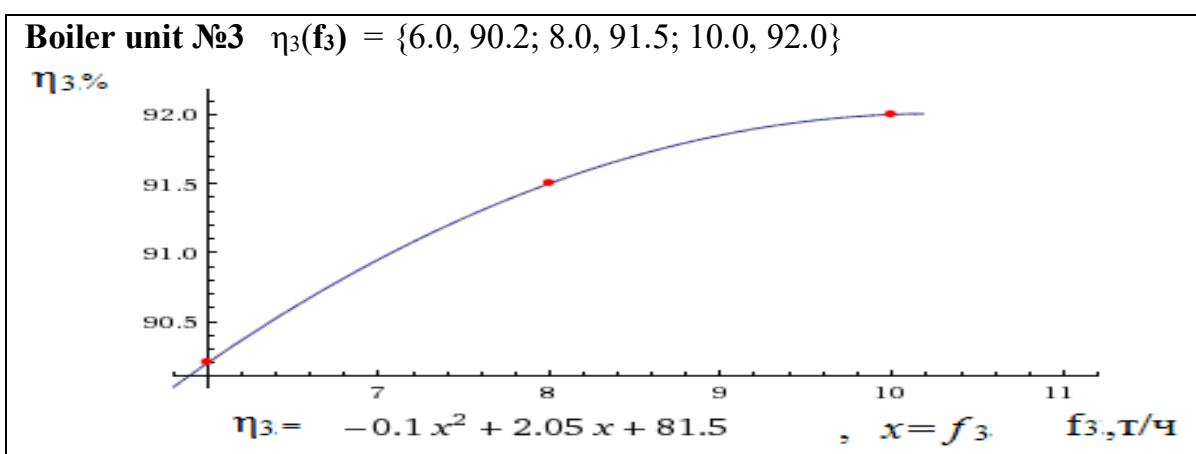

Boiler unit №4 $\quad \eta_{4}\left(\mathbf{f}_{4}\right)=\{6.0,88.5 ; 8.0,90.5 ; 10.0,91.0\}$

$\Upsilon_{4} \%$

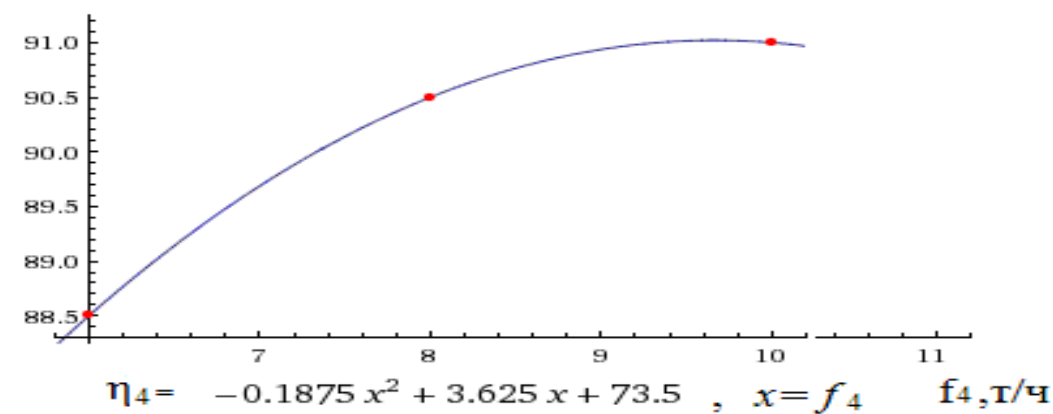

The fragment of program executed in specified environment notation is presented below:

[OCTAHOB1]

EvalStr $=\{\mathrm{s} 1\}>0$

[OCTAHOB2]

EvalStr $=\{\mathrm{s} 2\}>0$

[OCTAHOB3]

EvalStr $=\{\mathrm{s} 3\}>0$

[OCTAHOB4]

EvalStr $=\{\mathrm{s} 4\}>0$

[fn1 opt]

EvalStr $\left.=\left(\left(\{\mathrm{F}\}^{*}\{\mathrm{a} 2\}^{*}\{\mathrm{a} 3\}^{* 2-}\{\mathrm{a} 2\}+\{\mathrm{a} 3\}\right)^{*}\{\mathrm{~b} 1\}+\{\mathrm{a} 3\}^{*}\{\mathrm{~b} 2\}+\{\mathrm{a} 2\}^{*}\{\mathrm{~b} 3\}\right)\right)^{*} 0,5 /\left(\{\mathrm{a} 1\}^{*}\{\mathrm{a} 2\}+\{\mathrm{a} 1\}^{*}\{\mathrm{a} 3\}+\{\mathrm{a} 2\} *\{\mathrm{a} 3\}\right)$

[fn2_opt]

EvalStr $\left.=\left(\left(\{\mathrm{F}\}^{*}\{\mathrm{a} 1\}^{*}\{\mathrm{a} 3\}^{*} 2-\{\mathrm{a} 1\}+\{\mathrm{a} 3\}\right)^{*}\{\mathrm{~b} 2\}+\{\mathrm{b} 1\}^{*}\{\mathrm{a} 3\}+\{\mathrm{a} 1\}^{*}\{\mathrm{~b} 3\}\right)\right)^{*} 0,5 /\left(\{\mathrm{a} 1\}^{*}\{\mathrm{a} 2\}+\{\mathrm{a} 1\}^{*}\{\mathrm{a} 3\}+\{\mathrm{a} 3\}^{*}\{\mathrm{a} 2\}\right)$

[fn3_opt]

EvalStr $\left.=\left(\left(\{\mathrm{F}\} *\{\mathrm{a} 1\}^{*}\{\mathrm{a} 2\} * 2-\{\mathrm{a} 1\}+\{\mathrm{a} 2\}\right) *\{\mathrm{~b} 3\}+\{\mathrm{b} 2\} *\{\mathrm{a} 1\}+\{\mathrm{a} 2\} *\{\mathrm{~b} 1\}\right)\right)^{*} 0,5 /\left(\{\mathrm{a} 1\}^{*}\{\mathrm{a} 2\}+\{\mathrm{a} 1\} *\{\mathrm{a} 3\}+\{\mathrm{a} 3\} *\{\mathrm{a} 2\}\right)$

[OCTAHOB5]

EvalStr $=1$

[f5_t]

EvalStr $=12+\{$ И1 $\}$

[f_t]

EvalStr $=\{$ fn3_opt $\}+\{$ H1 $\}$

[f2_t]

EvalStr $=\{$ fn2_opt $\}+\{$ U1 $\}$

[f1_t]

EvalStr $=\{$ fn1_opt $\}+\{$ H1 $\}$

[kpd1 t $]$

EvalStr $=-0,025^{*}\{\text { fn1_opt }\}^{*}\{$ fn1_opt $\}+0,65^{*}\{$ fn1_opt $\}+87$

[kpd2_t]

EvalStr $=-0,164 *\left\{\mathrm{fn} 2 \_\right.$opt $\} *\left\{\mathrm{fn} 2 \_\right.$opt $\}+3,093 *\left\{\mathrm{fn} 2 \_\right.$opt $\}+77,79$ 
[kpd3_t]

EvalStr $=-0,1 *\{\mathrm{fn} 3$ opt $\} *\{\mathrm{fn} 3$ opt $\}+2,05 *\left\{\mathrm{fn} 3 \_\right.$opt $\}+81,5$

[0_kpd_t]

EvalStr $=\left(\left\{\mathrm{kpd} 1 \_\mathrm{t}\right\}+\left\{\mathrm{kpd} 2 \_\mathrm{t}\right\}+\left\{\mathrm{kpd} 3 \_\mathrm{t}\right\}\right) / 3$

[01_KPD_t]

EvalStr $=((-0,025 *(\{\mathrm{~F}\}-20) *(\{\mathrm{~F}\}-20)+0,65 *(\{\mathrm{~F}\}-20)+271,38)) / 3$

The main screen form of CHP plant head automated workplace is presented in Fig. 1.

The screen displays the main processing units used to implement the process: boiler units, turbo-aggregates, "hot" steam collector, reduction-cooling unit (RCU), air supply fans, high-pressure water pump, pipelines: water, steam, gas, air. In the lower right corner calcareous stove is represented, its work is included in tasks list where the CHP plant head is responsible. Clicking on corresponding button located inside the unit image, its detailed mnemonics appears. The boiler units' position (operation/stop) and process variables values are reflected in respective control points.

Data on boiler department control subsystem operation is shown in form of table in the form left corner. The boiler units' models energy-efficient parameters are given that can be specified during the repeated tests, the results of optimal values $f_{i}$ calculation, obtained estimations $\eta_{i}$, and boiler department general control criterion $\eta_{0}$ - efficiency factor on the base of required total steam flow $F$, distributed among identical operating boiler units (№1, №2, №3).

The repeated tests for boiler units to refine the parameters included in regime maps are conducted no more than 1-2 times per season, however, the current system information as part of automated workplace allow to find dependence parameters $\eta_{i}=\eta_{i}\left(f_{i}\right)$ at smaller time intervals [1], that helps to conduct more accurate calculations.

To test the efficiency of proposed control subsystem, simulation was performed in SCADA-system, where it is supposed to be implemented. For reasons of presentation, the numbering of boiler units is in reverse to factory numbering.

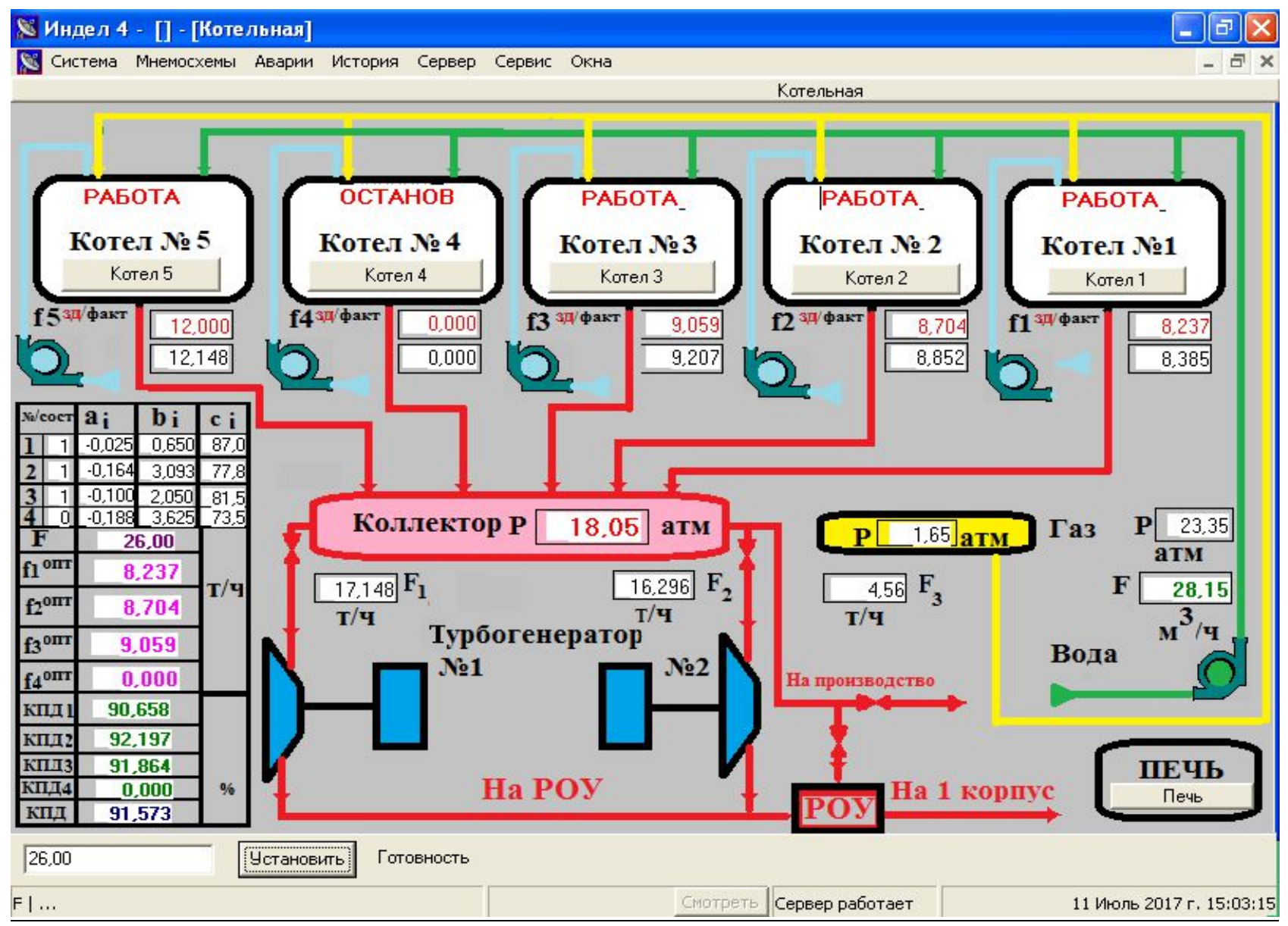

Fig. 1 - Screen form of CHP plant head automated workplace with control subsystem

The simulation results are presented in form of parametric and temporal graphs (with reduced time scale) when the total required steam flow is changed. 
Fig. 2 shows optimum boiler loads change graphs $f_{i}^{\text {opt }}$ with a stepwise change in total required steam flow rate $F$ in range from $23,0 \mathrm{t} / \mathrm{h}$ to $29,0 \mathrm{t} / \mathrm{h}$, at a pitch of $0,5 \mathrm{t} / \mathrm{h}$.

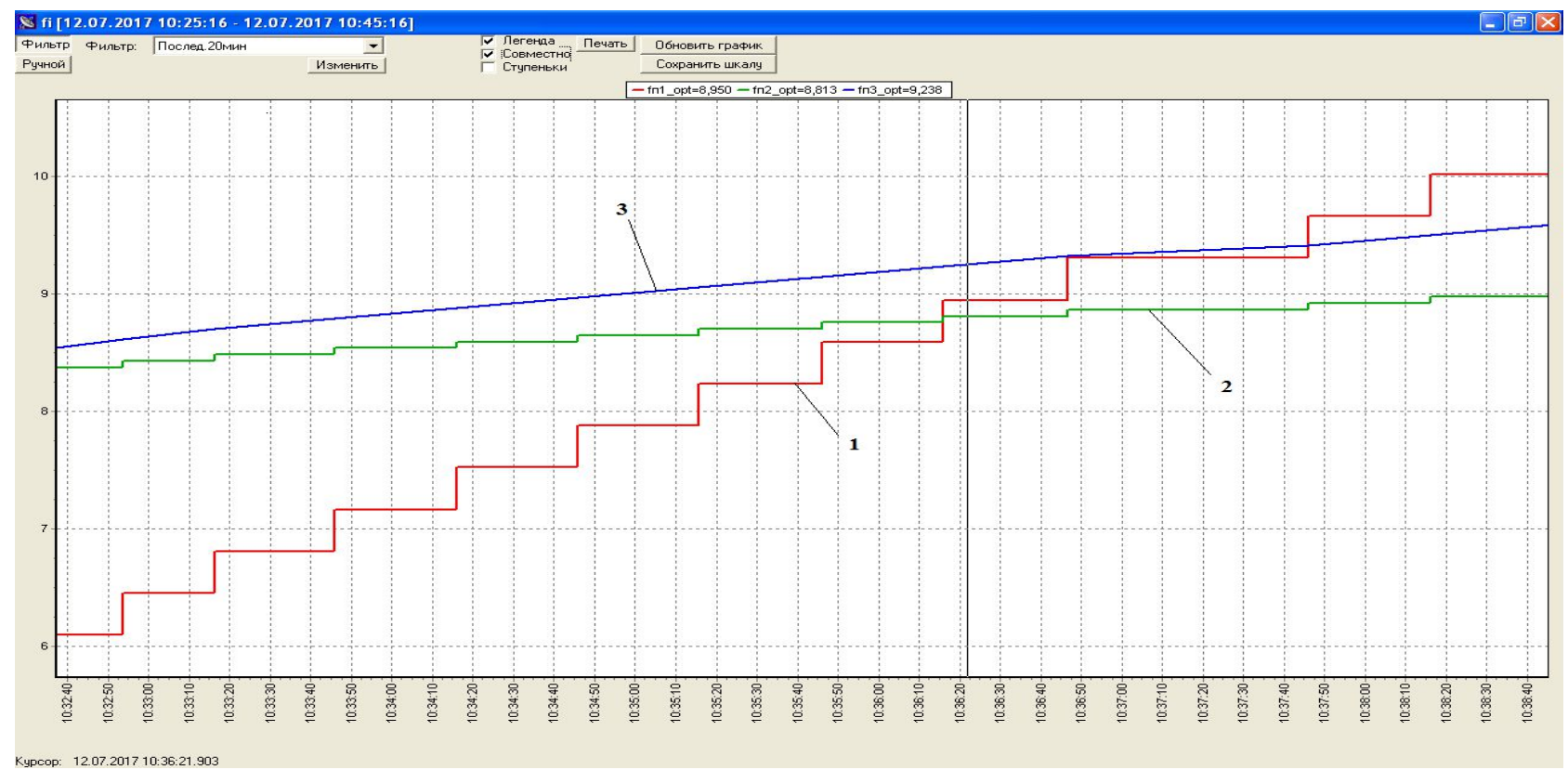

Fig. 2 - Change of optimum boiler unit loads, where 1, 2, 3 - numbering corresponding to boiler unit numbers

Fig. 3 shows the graphs of boiler units efficiency factor change $\eta_{i}(\%)$ and boiler department general control criterion (\%) with step change in total required steam flow rate $F$ in range from $23,0 \mathrm{t} / \mathrm{h}$ to $29,0 \mathrm{t} / \mathrm{h}$ at a pitch of $0,5 \mathrm{t} / \mathrm{h}$. The range of changes $F$ is determined based on the processing of plant data archives.

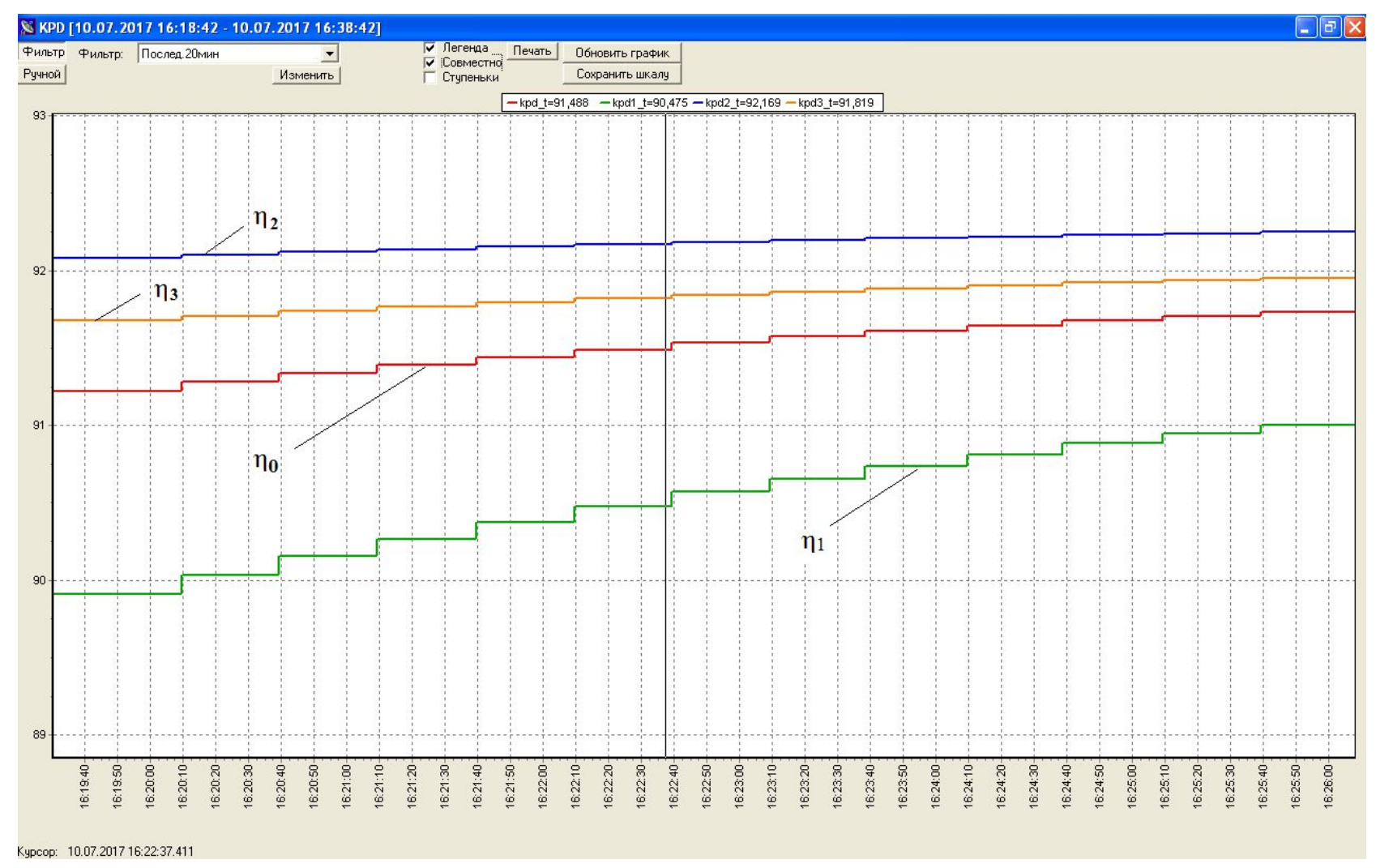

Fig. 3 - Boiler units efficiency factor change $\eta_{i}(\%)$ and boiler department general control criterion $\eta_{0}$ 
In simulation process, a comparative analysis of proposed boiler department control method was carried out based on optimal load distribution among parallel operating boiler units and the traditional one, where control is built on principle of separating several boiler units with a high efficiency factor to operate in basic mode and one to operate in regulating mode, that ensures pressure stabilization in common steam collector.

The option is considered, where boiler units №2 and №3 operate in basic mode with steam load $f_{i}=10 \mathrm{t} / \mathrm{h}, i=2,3$, while in accordance with energy efficiency characteristics $\eta_{2}=92,38 \%, \eta_{3}=92,0 \%$ are constant. Boiler unit №1 operates in regulating mode. The boiler department control criterion for both methods was considered as

$$
\eta_{0}=\sum_{i=1}^{n} \frac{\eta_{i}}{n}, i=1,2,3
$$

Fig. 4 is parametric graph of change in general control criterion when required steam flow rate $F$ is changed in range from 23,0 t/h to 29,0 t/h for proposed method and Fig. 5 is for traditional control method in same changes in flow rate $F$.

Comparative analysis shows that in entire range of change in flow rate $F$, the numerical values of control criterion for proposed method exceed the corresponding values for traditional one. However, it should be noted that at the beginning of changes range in flow rate $F$, difference among them is significant, so at $\mathrm{F}=23 \mathrm{t} / \mathrm{h}$, it is $0,436 \%$, and at $F=29 \mathrm{t} / \mathrm{h}, 0,076 \%$ respectively. In this case, the indicated difference in numerical values of control criterion nonlinearly decreases with steam flow rate $F$ increasing.

A clear illustration of noted above, is shown in Fig.6, where both the criterion change graphs for proposed control method $\eta_{0}(\%)$ and for traditional method $-\eta_{01}(\%)$ are given together, with step change at pitch of $0,5 \mathrm{t} / \mathrm{h}$ for required steam flow in range from $23,0 \mathrm{t} / \mathrm{h}$ to $29,0 \mathrm{t} / \mathrm{h}$.

Since maximum "hot" steam consumption for technological needs is typical for plant start-up periods to warm up the heatconsuming equipment and at the end of season, caused by deterioration in raw materials quality and heat-conducting characteristics of evaporators and heat exchangers, where the main period of sugar production season is characterized by consumption of recycle steam and relatively small consumption of "hot" steam. Thus, the feasibility of proposed control method is obvious, since boiler department efficiency factor increasing allows to reduce specific costs for natural gas and finished products cost.

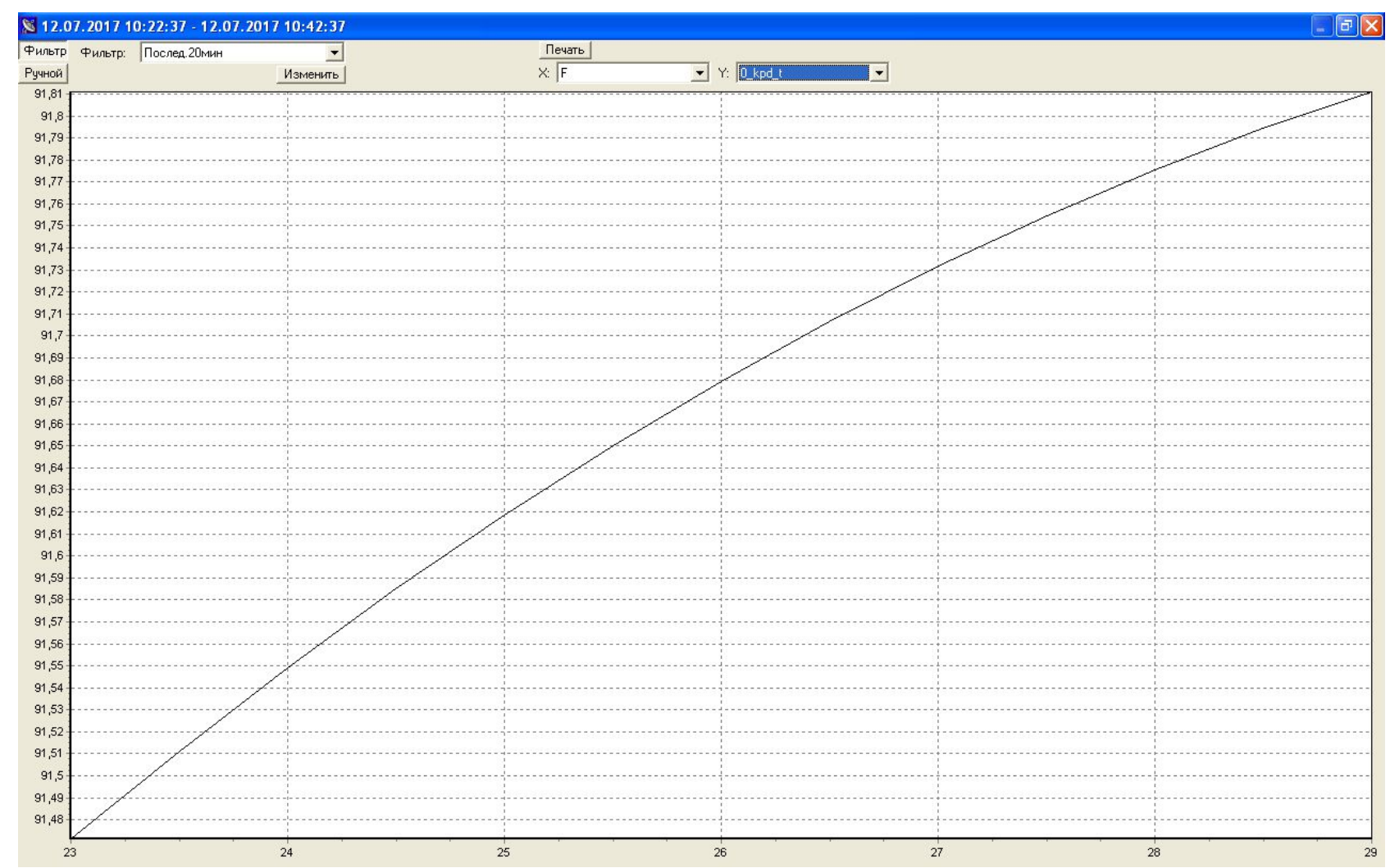

Fig. 4 - General control criterion change $\eta_{0}, \%$ when the required flow rate $F, t / h$, for the proposed control method is changed 


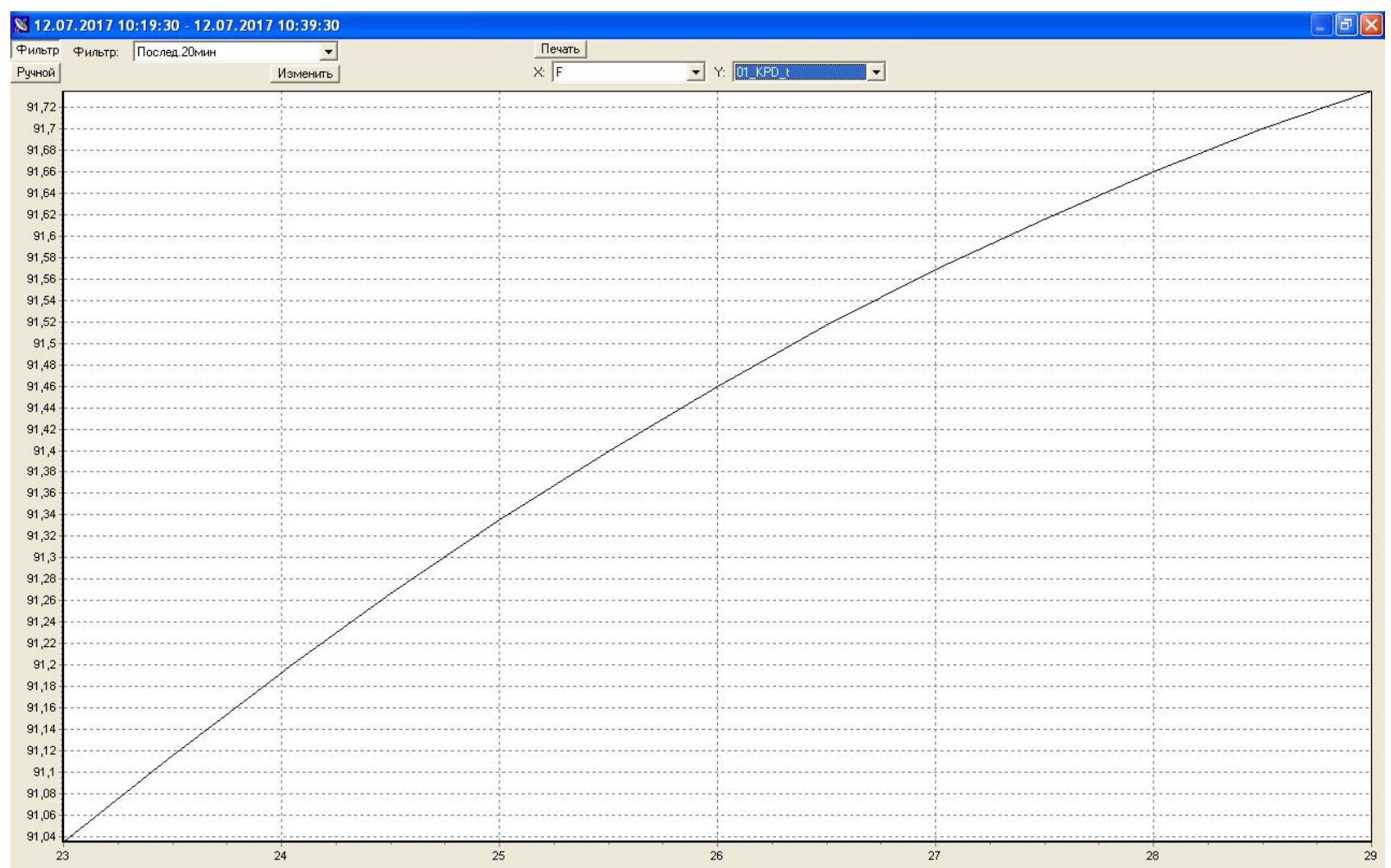

Fig. 5 - General control criterion change $\eta_{0}, \%$ when the required flow rate $F, t / h$, for traditional control method is changed

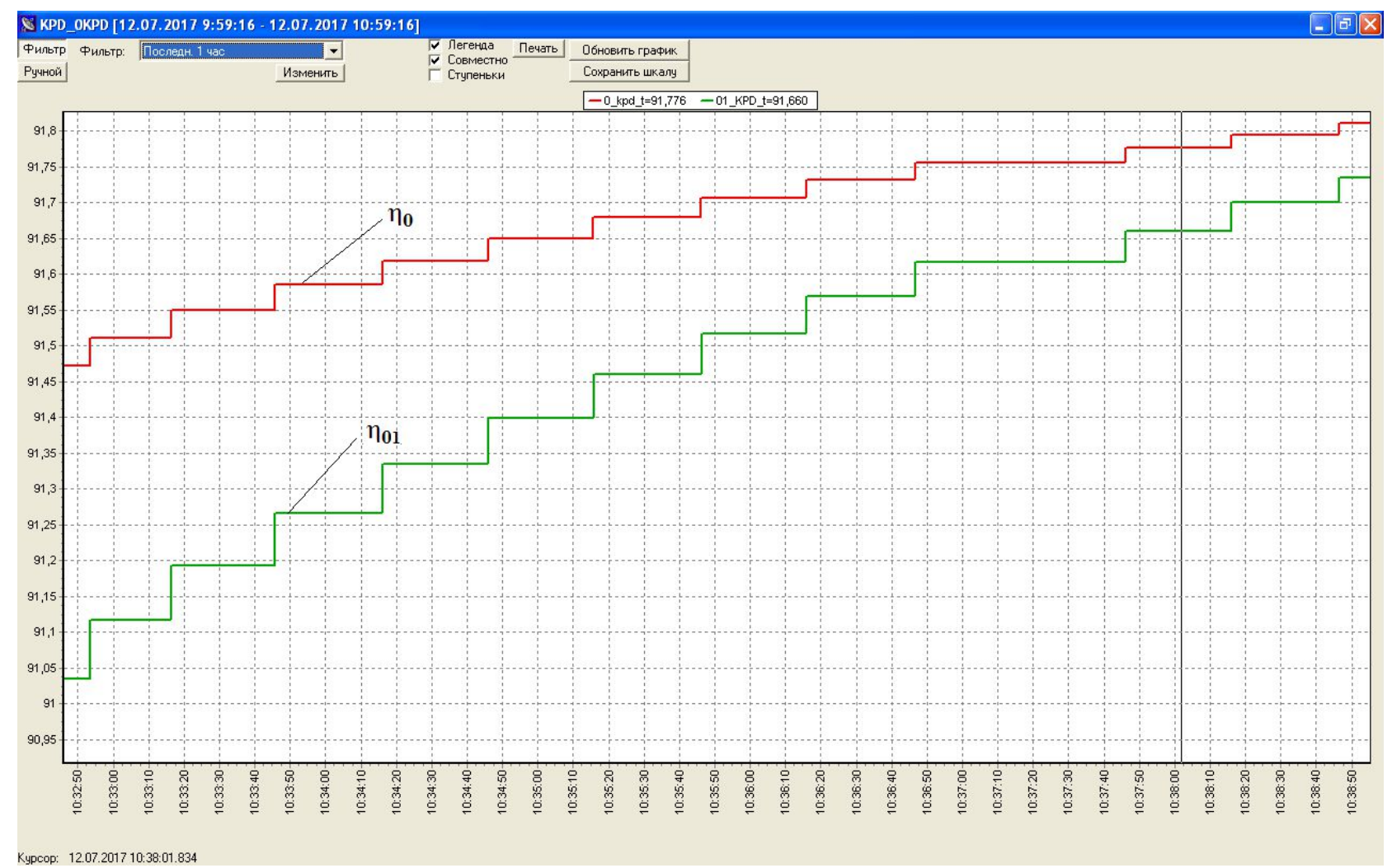

Fig. 6 -General control criterion change for proposed control method $\eta_{0}, \%$ and for traditional $\eta_{01}, \%$ 


\title{
Conclusions
}

As a result of laboratory tests and production surveys, method to increase boiler department efficiency, based on the principle of optimal load distribution among parallel boiler units was proposed. For boiler units operating on a common steam collector, and having close passport and different energy efficiency characteristics, analytical formulas were obtained to determine optimal loads values for each boiler included in operation. Algorithm and calculation program have been developed, as well as main screen form for CHP plant head automated workplace. The optimum load values of each boiler unit are used as tasks in boiler load stabilization circuit in period among calculations. The efficiency of control subsystem and advantages of proposed control method is confirmed by simulation modeling methods in comparison with traditional one. Research results will be used to modernize the existing control system at the sugar plant and in the educational process.

\section{References}

[1] Y. M. Skakovsky V. Babkov, E. Y. Mandro Increasing of precise estimation of optimal criteria boiler functioning. Odessa, Automation of technological and business-processes, Volume 8, Issue 2, pp. 58-65, 2016.

[2] Y. M. Skakovsky A. V. Babkov Patent na korisnu model №108607 Ukraine, MPK F 23N 1/02, Sposib avtomatichnogo keruvannia, kontrolu, zakhistu ta signalizacii kotloagregatu, July 25, 2016, ONAFT, p. 6, 2016.

[3] Y. M. Skakovsky Vikoristannia tekhnologii "tonkikh klientiv” dlia stvorennia informaciynoi sistemi kotelnogo viddilennia v TEC cukrozavodu. Odessa, Avtomatizacia tehnologicheskih i biznes-procesov, issue 17, pp. 8-10, 2014.

[4] A. I. Boiarinov Metodi optimizacii v kimicheskoy teknologii. M., “Kimia”, p. 576, 1975.

\section{Література}

[1] Skakovsky Y. M. Increasing of precise estimation of optimal criteria boiler functioning / Y. M. Skakovsky, V. Babkov, E. Y. Mandro // Automation of technological and business-processes. - Odessa: Volume 8, Issue 2/2016/, p. 58-65.

[2] Скаковський Ю.М. Патент на корисну модель №108607 Україна, MPK F 23N 1/02, Спосіб автоматичного керування, контролю, захисту та сигналізації / Скаковський Ю.М., Бабков А.В.; ОНАХТ. - публ.: 25.07.2016, Bul. №14, 2016. - C. 6.

[3] Скаковский Ю. М. Використання технологіi “тонких клієнтів” для створенніая інформаційної системи котелного відділення в ТЕЦ цукрозаводу / Скаковский Ю.М., Бабков А.В. //Автоматізація технологічних та бізнес-процесів. - Одеса: 2014 - №17. - С. 8-10.

[4] Бояринов А. И. Методы оптимізации в химической технологии / Бояринов А.И., Кафаров В.В. - М.: “Химия”, 1975. $-576 \mathrm{c}$.

UDC 681.51

\section{FEATURES OF THE MOBILE ROBOTS CONTROL SYSTEMS}

\author{
S. Ihnatiev ${ }^{1}$, V. Yehorov ${ }^{2}$ \\ ${ }^{1,2}$ Odessa National Academy of Food Technologies, Odessa, Ukraine \\ ORCID: ${ }^{1} 0000-0001-8431-221 \mathrm{X},{ }^{2} 0000-0003-4699-834 \mathrm{X}$ \\ E-mail: ${ }^{1}$ igsergo@gmail.com, ${ }^{2}$ yegorov.onaft@gmail.com
}

Copyright (C) 2017 by author and the journal "Automation technological and business - processes". This work is licensed under the Creative Commons Attribution International License (CC BY). http://creativecommons.org/licenses/by/4.0/

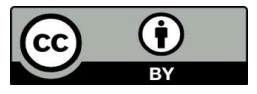

ONAFT

Open Access

Abstract: The article is devoted to mobile robots. Mobile robots are devices that can move autonomously to accomplish their goals. As the title implies the article describes traffic guidance systems for the mobile robots. A generalized scheme of the mobile robots control systems is shown. It compiles on the basis of the hierarchical principle. Attention is paid to each level of 